Gut, 1987, 28, 1215-1220

\title{
In vitro stimulation of pancreatic enzyme discharge by calcium
}

\author{
P LAYER, J HOTZ, L CHERIAN, AND H GOEBELL
}

From the Division of Gastroenterology, Department of Medicine, University of Essen, Federal Republic of Germany

SUMmARY The mechanism for acute hypercalcaemia increasing pancreatic enzyme secretion is unknown. To determine if raised extracellular calcium concentrations can directly stimulate pancreatic enzyme output, we measured discharges of pulse labelled protein and chymotrypsin from isolated cat pancreatic lobules in the presence of normal and raised calcium concentrations. Incubation in $5.0 \mathrm{mmol} / \mathrm{l}$ calcium increased discharges of pulse labelled protein (four fold), chymotrypsin ( 2.5 fold) and amylase ( 2.2 fold), compared with control experiments with 2.5 $\mathrm{mmol} / \mathrm{l}$ calcium $(\mathrm{p}<0 \cdot 001)$. This effect was similar to the maximal effect of carbachol or caerulein. Compared with $5.0 \mathrm{mmol} / \mathrm{l}$ calcium, incubation at the higher calcium concentration of $10.0 \mathrm{mmol} / \mathrm{l}$ induced similar discharges of chymotrypsin and amylase, whereas the increase in discharge of pulse labelled protein was smaller $(\mathrm{p}<0 \cdot 01)$. The effects of raised calcium were not altered by atropine. Incubation in a high calcium medium did not impair pancreatic acinar response to subsequent stimulation with carbachol, but incubation in hypothermia abolished the effects of high calcium concentrations, suggesting that increased enzyme discharge is caused by stimulation of secretion not to cell damage. These data are consistent with a direct stimulatory effect of raised extracellular calcium concentrations on pancreatic acinar cell function.

Acute experimental hypercalcaemia is a potent stimulus of pancreatic enzyme secretion in man and cats. ${ }^{1-}$ These findings may be of clinical relevance because hypercalcaemic syndromes, ${ }^{56}$ in particular acute hypercalcaemic crises, ${ }^{7 \times}$ may be complicated by pancreatitis. The mechanism whereby hypercalcaemia mediates stimulation of enzyme secretion is unknown. In vivo studies in cats suggested that indirect pathways such as cholinergic excitation or release of stimulatory gastrointestinal hormones induced by high serum calcium concentrations could not fully explain the effects of hypercalcaemia on pancreatic function." Thus, cellular mechanisms might also be involved.

The aim of the present study was to investigate whether a rise in extracellular calcium concentrations

Address for correspondence: Peter Layer. MD. Division of Gastroenterologie, Department of Medicine, University of Essen, Hufelandstr. 55, D-4300 Essen 1. FR Germany.

Received for publication 20 February 1987 can directly stimulate secretion of enzymes from the pancreas. Utilising an in vitro model of isolated cat pancreatic lobules, we determined the effects of raised calcium concentrations in the incubation medium on enzyme discharge, compared with the effects of the secretagogues carbachol and caerulein.

\section{Methods}

PREPARATION OF CAT PANCREATIC LOBULES Healthy cats of either sex were anaesthetised (intraperitoneal pentobarbital, $30 \mathrm{mg} / \mathrm{kg}$ body weight, after an overnight fast of $16 \mathrm{~h}$ with free access to water) and killed by aortic exsanguination. The pancreas (3-4 g wet wt) was removed immediately and submerged and rinsed thoroughly in ice cold modified Krebs-Ringer buffer solution. The buffer was altered by replacing bicarbonate with $\mathrm{N}-2$ hydroxyethyl-piperazine-2 ethane sulfonic acid (HEPES) at $15 \mathrm{mmol} / \mathrm{l}$ and $\mathrm{pH} 7 \cdot 4$, and by addition of 1215 
glucose at $14 \mathrm{mmol} / \mathrm{l}$ and Eagle's mixture of essential and non-essential amino acids" ${ }^{10}$ except leucine (KRH-buffer). Pancreatic lobules (5-6 mg each) were prepared essentially as described by Scheele and Palade," adapted to feline pancreatic tissue.

\section{PULSE LABELLING}

Secretory proteins were radiolabelled using a modification $^{12}$ of the original procedure described by Jamieson and Palade. ${ }^{13}$ Briefly, pancreatic lobules were pulsed with $\mathrm{L}\left[4,5-{ }^{3} \mathrm{H}\right]$ leucine $(5 \mu \mathrm{Ci} / \mathrm{ml})$, the flask being first kept on ice for 10 minutes, then incubated at $37^{\circ} \mathrm{C}$ for 20 minutes under $100 \% \mathrm{O}_{2}$ atmosphere. Lobules were then removed and washed thoroughly with warm chase medium and then transferred to and incubated in one of the experimental media described below.

\section{INCUBATION AND SAMPLING}

After pulse labelling, experiments were carried out in KRH-buffer containing non-radioactive leucine $(0.34 \mathrm{mmol} / \mathrm{l})$ and bovine serum albumine (600 $\mathrm{mg} / \mathrm{l})^{12}$ with 20 lobules/flask $(5 \mathrm{ml})$ at $37^{\circ} \mathrm{C}$ (unless indicated otherwise) and under $100 \% \mathrm{O}_{2}$ atmosphere. In experiments where the calcium concentration was increased, sodium chloride concentrations were adjusted appropriately to maintain isotonicity. Constancy of the medium $\mathrm{pH}$ of 7.4 was verified at regular intervals. To assess acinar enzyme output during the experiment, $2.5 \mathrm{ml}$ aliquots of the medium were removed at $0,60,120$, and 180 minutes of incubation for analyses and replaced by new medium. From this $2.5 \mathrm{ml}$, after immediate measurement of $\mathrm{pH}$ and ionised calcium concentration, $2.0 \mathrm{ml}$ were precipitated with $10 \%$ TCA for determination of radiolabelled protein, and $0.5 \mathrm{ml}$ were used for chymotrypsin, amylase, and total calcium assays. After the end of the experiments the pancreatic lobules were washed and homogenised in $5 \mathrm{ml}$ cold distilled water. Of the homogenate, $1 \mathrm{ml}$ was used for chymotrypsin and amylase determinations and two $1 \mathrm{ml}$ aliquots of the remainder were precipitated with TCA.

\section{EXPERIMENTAL INCUBATION MEDIA}

In control experiments, experimental medium contained calcium at $2.5 \mathrm{mmol} / \mathrm{l}(\mathrm{n}=15$ experiments $)$, and no secretagogues. An additional set of six control experiments was carried out at a medium calcium concentration of $1.25 \mathrm{mmol} / \mathrm{l}$, because this reflects the free calcium concentration in feline plasma in vivo (own unpublished data). The effects of carbachol (Sigma, Munich, FRG) and caerulein (Montedison, Freiburg, FRG) were determined in dose response studies at the control calcium concentration of $2.5 \mathrm{mmol} / \mathrm{l}$. The dose response of carbachol was determined at concentrations of $5 \times 10{ }^{~ "} \mathrm{M}$ $(n=8), 5 \times 10^{7} M(n=8)$ and $5 \times 10^{5} M(n=8)$, and that of caerulein at concentrations of $6 \cdot 2 \times 10^{11} \mathrm{M}$ $(\mathrm{n}=8), 6 \cdot 2 \times 10^{11} \mathrm{M}(\mathrm{n}=8)$, and $6 \cdot 2 \times 10^{\circ} \mathrm{M}(\mathrm{n}=8)$. The effect of raised extracellular calcium concentrations was studied at calcium concentrations of $5 \cdot()$ $\mathrm{mmol} / \mathrm{l}(\mathrm{n}=16)$ - that is, a concentration observed clinically in hypercalcaemic crisis and known to stimulate pancreatic enzyme secretion in vivo, and $10 \cdot 0 \mathrm{mmol} / \mathrm{l}(\mathrm{n}=10)$.

To determine whether the effect of high extracellular calcium concentrations on enzyme discharge could be mediated via release of acetylcholine from cholinergic nerve terminals, we added atropine sulphate to the incubation medium in a further set of experiments. The concentrations of atropine tested were $10^{-4} \mathrm{M}, 10^{-7} \mathrm{M}$, and $10^{5} \mathrm{M}$, each at a calcium concentration of either 2.5 or $5.0 \mathrm{mmol} / \mathrm{l}(\mathrm{n}=6$ each group).

To assess if high calcium concentrations in the medium cause irreversible acinar cell damage, acinar secretory capacity was examined after incubation with high calcium concentrations in additional experiments: Lobules were first incubated at $37^{\circ} \mathrm{C}$ in high $(5.0 \mathrm{mmol} / \mathrm{l})$ calcium medium for 120 minutes, then washed thoroughly and incubated in control medium (calcium concentration: $2.5 \mathrm{mmol} / \mathrm{l}$ ) for 60 minutes, and finally incubated in carbachol $\left(5 \times 10^{7}\right.$ M) medium for another 60 minutes.

To determine if the calcium induced enzyme discharge could be caused by unspecific leakage from damaged acinar cells or is an energy dependent process, lobules were incubated at $1{ }^{\circ} \mathrm{C}$ with carbachol $\left(5 \times 10^{-7} \mathrm{M} ; \mathrm{n}=5\right)$ or calcium $(5.0 \mathrm{mmol} / \mathrm{l}$; $\mathrm{n}=5$ ) at their maximally effective concentrations, or in control medium (with $2.5 \mathrm{mmol} / \mathrm{l}$ calcium and without secretagogue).

\section{STATISTICAL ANALYSES}

Total calcium concentration in the incubation medium was determined by a fluorimetric method using back titration with ethylene glycol bis (betaaminoethylether)-tetraacetic acid (EGTA) on a Corning 940 Titrator (Corning Ltd, Giessen, FRG). ${ }^{13}$ Ionised calcium concentration in the medium was measured by a calcium selective ion exchange electrode (Ion 83 Ion Meter, Radiometer, Copenhagen, Denmark. ${ }^{1+15}$ TCA-precipitable radioactivity served as a measure of pulse-labelled - that is, newly synthesised, protein. ${ }^{16}$ After overnight precipitation of samples from incubation media and homogenates with $10 \%$ TCA, precipitates were washed twice with $5 \% \mathrm{TCA}$. The final pellet was dissolved in $1 \mathrm{ml} 1 \mathrm{~N}$ $\mathrm{NaOH}$ and transferred to scintillation counting vials with $10 \mathrm{ml}$ Unisolve (Koch-Light Laboratories, Colnbrook, England), which forms a gel after 
addition of $3 \mathrm{ml}$ distilled water. Radioactivity was determined in a Packard liquid scintillation counter and corrected for quenching and background. Chymotrypsin and amylase served as a measure of total (preformed and newly synthesised) enzyme. Chymotrypsin activity was determined by using Nbenzoyl-L-tyrosine-ethyl-ester (BTEE) as a substrate, after incubation with enterokinase $(0 \cdot 40$ $\mathrm{mg} / \mathrm{ml}$; Hoechst, Frankfurt, FRG) in the presence of $50 \mathrm{mmol} / \mathrm{l}$ calcium for 60 minutes at $25^{\circ} \mathrm{C},{ }^{17}$ and amylase according to the method described by Bernfeld. ${ }^{1 *}$ Discharges of radiolabelled protein, chymotrypsin and amylase into the medium per hour were corrected for the amounts removed by sampling, and expressed as per cent of total contents. Total contents were calculated from the sum of cumulative discharge into the medium and content of homogenates at end of incubation. Each individual experiment was done in quadruplicate - that is, using four identical incubates containing 20 lobules each. The mean values among these incubates were calculated. The numbers of experiments within each experimental group are given above (Experimental Incubation Media). Experimental groups were compared by unpaired t-tests, ${ }^{19}$ and data expressed as mean values + standard deviation (SD).

\section{Results}

RESPONSE TO SECRETAGOGUES

In control experiments using incubate calcium concentrations of 2.5 or $1.25 \mathrm{mmol} / \mathrm{l}$, mean total calcium

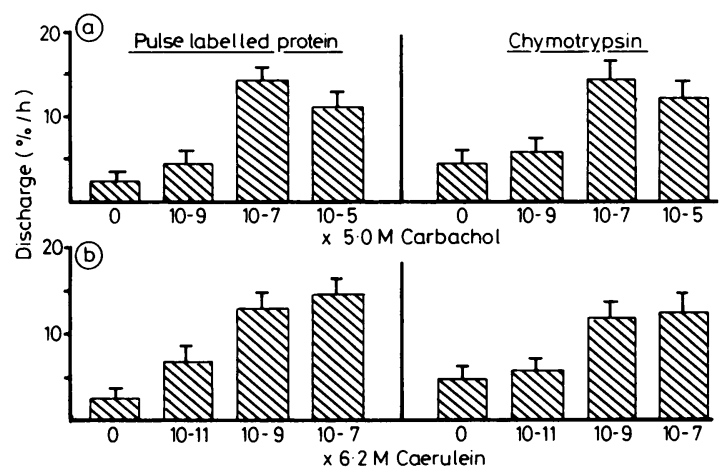

Fig. 1 (a) Discharge of pulse labelled protein (left panel) and chymotrypsin (right panel) in response to graded concentrations of carbachol at a calcium concentration of $2 \cdot 5$ mmolll. Data are expressed as the per cent of total content discharged per hour during the final two hours of incubation (mean values $\pm S D$ ). (b) Discharge of pulse labelled protein (left panel) and chymotrypsin (right panel) in response to graded concentrations of caerulein at a calcium concentration of $2.5 \mathrm{mmol} / \mathrm{l}$. Data are expressed as the per cent of total content discharged per hour during the final two hours of incubation (mean values $\pm S D$ ). concentrations in the samples were $1 \cdot 26 \pm 0.01$ $\mathrm{mmol} / \mathrm{l}$ or $2.52 \pm 0.03 \mathrm{mmol} / \mathrm{l}$, and mean ionised calcium concentrations were $1 \cdot 14 \pm 0 \cdot 05 \mathrm{mmol} / \mathrm{l}$ or $2.42 \pm 0.10 \mathrm{mmol} / \mathrm{l}$, respectively; both, total and ionised calcium concentrations varied by $<2 \%$ throughout experiments. In these studies - that is, in the absence of secretagogues and with 2.5 or 1.25 $\mathrm{mmol} / \mathrm{l}$ of calcium in the incubation medium, discharges of pulse labelled protein were $2 \cdot 3 \pm 0 \cdot 5 \% / \mathrm{h}$ or $2 \cdot 4 \pm 0 \cdot 8 \% / \mathrm{h}$, of chymotrypsin $4 \cdot 0 \pm 1 \cdot 0 \% / \mathrm{h}$ or $4 \cdot 2 \pm 1 \cdot 2 \% / \mathrm{h}$, and of amylase $3 \cdot 8 \pm 1 \cdot 2 \% / \mathrm{h}$ or $3 \cdot 9 \pm 1 \cdot 4 \% / \mathrm{h}$, respectively.

In the presence of carbachol, discharges of radioactivity, chymotrypsin and amylase were increased $(p<0.001)$; the greatest responses were observed at a carbachol concentration of $5 \times 10^{-7} \mathrm{M}$ (Fig. 1a). Similarly, addition of caerulein to the incubation medium increased radioactivity, chymotrypsin, and amylase discharges into the medium $(\mathrm{p}<0.001)$, with similar effectiveness of $6.2 \times 10^{-11} \mathrm{M}$ and $6.2 \times 10^{-9} \mathrm{M}$ (Fig. 1b).

\section{RESPONSE TO RAISED CALCIUM}

CONCENTRATIONS

In the experiments with increased calcium concentrations of 5.0 or $10.0 \mathrm{mmol} / \mathrm{l}$, mean total calcium concentrations were $5 \cdot 07 \pm 0 \cdot 08 \mathrm{mmol} / \mathrm{l}$ or $9 \cdot 96 \pm 0 \cdot 38$ $\mathrm{mmol} / \mathrm{l}$, respectively, and mean ionised calcium concentrations were $4 \cdot 92 \pm 0 \cdot 12 \mathrm{mmol} / \mathrm{l}$ or $0 \cdot 72 \pm 0 \cdot 16$ $\mathrm{mmol} / \mathrm{l}$, respectively; both total and ionised calcium concentrations remained virtually constant throughout experiments, with variations of $<3 \%$. During both raised calcium concentrations, discharges of pulse labelled protein, chymotrypsin and amylase were markedly increased, compared with control experiments $(p<0.001)$. The greatest effect was observed at a calcium concentration of $5.0 \mathrm{mmol} / \mathrm{l}$, when discharge of pulse labelled protein was four times greater than in control experiments. Similar changes occurred in chymotrypsin (Fig. 2) and amylase discharges which increased 2.5 fold and 2.2 fold, respectively, in response to $5.0 \mathrm{mmol} / \mathrm{l}$ calcium. These responses were similar to the maximal effects

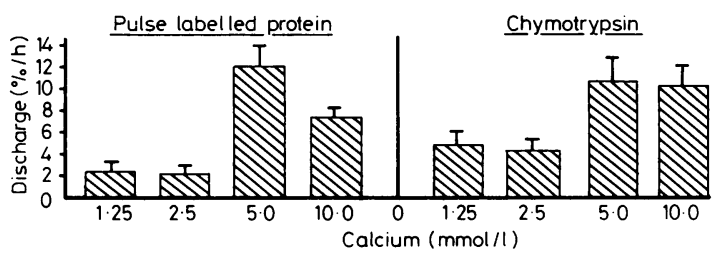

Fig. 2 Discharge of pulse labelled protein (left panel) and chymotrypsin (right panel) in response to calcium concentrations of $1 \cdot 25,2 \cdot 5,5 \cdot 0$, and $10 \cdot 0 \mathrm{mmol} / \mathrm{l}$. Data are expressed as the per cent of total content discharged per hour during the final two hours of incubation (mean values $\pm S D$ ). 


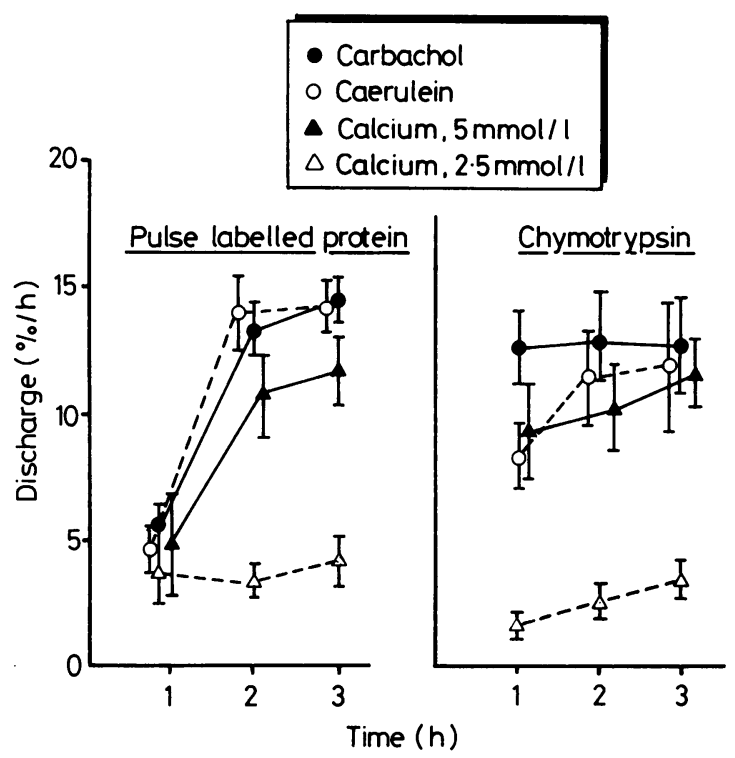

Fig. 3 Kinetics of discharge of pulse labelled protein (left panel) and of chymotrypsin (right panel) in response to raised extracellular calcium concentrations $(5.0 \mathrm{mmol} / \mathrm{l}$; solid triangles) compared with responses to carbachol $\left(5 \times 10^{-7} \mathrm{M}\right.$; solid circles $)$ and caerulein $\left(6 \cdot 2 \times 10^{-9} \mathrm{M}\right.$; open circles), and with control experiments (calcium concentration: $2.5 \mathrm{mmol} / \mathrm{l}$, no secretagogues; open triangles).

of carbachol or caerulein (Fig. 3). At a calcium concentration of $10 \cdot 0 \mathrm{mmol} / \mathrm{l}$ there was no further increase in chymotrypsin or amylase release, while discharge of pulse labelled protein was significantly smaller, compared with $5 \mathrm{mmol} / \mathrm{l}(\mathrm{p}<0.001)$ (Fig. 2).

\section{EFFECT OF ATROPINE}

Incubation with $10^{-9} \mathrm{M}, 10^{-7} \mathrm{M}$, or $10^{-5} \mathrm{M}$ atropine did not significantly influence discharge of protein or enzyme, neither at control nor at raised calcium concentrations. At a calcium concentration of 2.5 $\mathrm{mmol} / \mathrm{l}$, discharges of pulse labelled protein were $2 \cdot 5 \pm 0 \cdot 2,2 \cdot 5 \pm 0 \cdot 3$, or $2 \cdot 4 \pm 0 \cdot 2 \% / \mathrm{h}$, respectively, while discharges of chymotrypsin were $4 \cdot 6 \pm 0 \cdot 2$, $4 \cdot 4 \pm 0 \cdot 3$, or $4 \cdot 3 \pm 0 \cdot 3 \% / \mathrm{h}$, respectively. At a raised calcium concentration of $5.0 \mathrm{mmol} / \mathrm{l}$ in the presence of the same concentrations of atropine, discharge of pulse labelled protein was $10 \cdot 0 \pm 0 \cdot 7,9 \cdot 8 \pm 0 \cdot 6$ and $10 \cdot 7 \pm 0 \cdot 5 \% / \mathrm{h}$, respectively, and of chymotrypsin $13 \cdot 2 \pm 1 \cdot 2,12 \cdot 3 \pm 1 \cdot 1$, and $13 \cdot 1 \pm 0 \cdot 8 \% / \mathrm{h}$, respectively.

\section{RESTIMULATION AFTER HIGH CALCIUM} INCUBATION

Incubation of pancreatic lobules at high calcium concentrations (at $5.0 \mathrm{mmol} / \mathrm{l}$ ) for two hours did not alter their responsiveness to subsequent restimula- tion with carbachol at $5 \times 10^{7} \mathrm{M}$, compared with controls without calcium preincubation: carbachol increased discharge of radio labelled protein to $14.4 \pm 0.7 \% / \mathrm{h}$, compared with $13.4 \pm 1.0 \% / \mathrm{h}$ in controls. Discharges of chymotrypsin were increased to $11.9 \pm 1.5 \% / \mathrm{h}$ and $12 \cdot 6 \pm 2 \cdot 2 \% / \mathrm{h}$ with and without pre-exposure to high calcium, respectively.

\section{EFFECT OF HYPOTHERMIA}

When lobules were incubated at $1^{\circ} \mathrm{C}$, presence of either high calcium concentrations $(5.0 \mathrm{mmol} / \mathrm{l})$ or carbachol $\left(5 \cdot 10^{-7} \mathrm{M}\right)$ did not increase discharge of chymotrypsin $(2 \cdot 8 \pm 0 \cdot 5 \% / \mathrm{h}$ and $3 \cdot 2 \pm 0 \cdot 6 \% / \mathrm{h}$, respectively) compared with control lobules incubated without carbachol and at $2.5 \mathrm{mmol} / \mathrm{l}$ calcium $(2 \cdot 9 \pm 0 \cdot 8 \% / \mathrm{h})$. Similarly, discharge of pulse labelled protein was very low $(0 \cdot 6 \pm 0 \cdot 1 \% / \mathrm{h}$ in the presence of high calcium, $0 \cdot 7 \pm 0 \cdot 2 \% / \mathrm{h}$ in the presence of carbachol, and $0 \cdot 5 \pm 0 \cdot 1 \% / \mathrm{h}$ in controls).

\section{Discussion}

Our findings show that discharge of digestive enzymes and newly synthesised protein from feline pancreatic tissue in vitro increases in the presence of raised calcium concentrations in the bathing medium. This increase reaches the magnitude of the response to maximal stimulation with carbachol or caerulein and is not inhibited by atropine. Further, after exposure to high calcium concentrations, pancreatic responsiveness to subsequent secretagogue stimulation is not impaired, and in hypothermia incubation of pancreatic lobules in high calcium medium does not result in increased enzyme discharge. Thus, it is unlikely that the increased appearance of pancreatic enzyme in the medium is because of acinar cell damage caused by supraphysiologic calcium concentrations. Rather it appears that rises in extracellular calcium concentrations induce stimulation of secretion. We observed that discharge of newly synthesised protein was lower at $10 \mathrm{mmol} / \mathrm{l}$ calcium compared with $5 \mathrm{mmol} / \mathrm{l}$ calcium, possibly reflecting a supramaximal effect. On the other hand, it is also conceivable that at excessive calcium concentrations intracellular function as well as morphology may be altered. ${ }^{21}$ In a number of experiments we have monitored ionised, in addition to total, calcium concentrations in the incubation medium to exclude that the presence of albumin, amino acids and tissue in the incubate may have grossly influenced the free, biologically relevant medium calcium concentration. More than $95 \%$ of the calcium were and remained ionised throughout experiments, however.

The effect of a disturbed calcium homeostasis on pancreatic function are of clinical interest because 
hypercalcaemia can cause pancreatic disease. This interest prompted several earlier studies that have shown a stimulatory effect of acute rises in serum calcium concentrations on pancreatic enzyme secretion in man. ${ }^{1-3}$ The mechanism by which hypercalcaemia increased enzyme secretion has not been fully elucidated, however, as species differences render it difficult to establish an appropriate animal model in common laboratory species, such as dogs or rats, ${ }^{21}{ }^{22}$ whereas feline pancreatic responses to hypercalcaemia are similar to those in man. ${ }^{49}$

Also data on potential neural or humoral mediation of the pancreatic responses to hypercalcaemia are presently inconclusive. Hypercalcaemia induces complex effects on release of several potential neural (such as acetylcholine) ${ }^{23}$ and humoral (such as cholecystokinin) ${ }^{4}$ stimulatory mediators. On the other hand, the calcium induced increase in pancreatic secretion in vivo is not inhibited by atropine, suggesting that cholinergic excitation is not a major mechanism. " Our present finding in vitro supports this conclusion because atropine has no effect on the response to high calcium concentrations. Other in vivo experiments in the cat suggest that the calcium induced increase in plasma cholecystokinin is not likely the only responsible mechanism. ${ }^{9}$

Another potential mechanism of the effects of hypercalcaemia is direct acinar stimulation by high extracellular calcium levels - for example through excitation of the cell membrane, or by enhanced entry of calcium from the extracellular fluid into the cytosol, similar to the mode of action of the calcium ionophor A 23187. In previous studies using the isolated perfused pancreas, conflicting results have been reported: increased pancreatic enzyme outputs in response to rises in calcium concentrations in the perfusate were observed in two studies ${ }^{2+25}$ but not in others. ${ }^{26}{ }^{27}$ The results obtained in the present study using isolated feline pancreatic lobules now suggest, that high extracellular calcium concentrations induce marked stimulation of enzyme discharge. This stimulation is not prevented by atropine and therefore probably not mediated by endogenous release of acetylcholine from nerve terminals preserved within the preparation. Involvement of other, noncholinergic mediatory mechanisms such as calcium induced neural release of intrinsic peptidergic stimulatory neurotransmitters is not positively excluded by our data, because a feline isolated acinar preparation was not available to us at the time of the study. There is indirect evidence, however, against a major role of such a hypothetical neural mechanism; the strong stimulation of enzyme secretion from the isolated perfused cat pancreas in response to potassium induced depolarisation of intrapancreatic nerves has been shown to be completely prevented by atropine but not by ganglionic blockade, and thus to be exclusively mediated by intrinsic release of acetylcholine. ${ }^{2 x}$ Therefore it is unlikely that neural, atropine resistant, non-cholinergic pathways are responsible for the stimulatory effect of extracellular calcium concentrations on pancreatic enzyme discharge in vitro.

There are several similarities between pancreatic secretory responses in vivo and in vitro to raised calcium concentrations: the maximally effective calcium concentrations in vitro are in the same range as the maximally effective serum calcium concentrations in vivo $;{ }^{\prime}$ the maximal calcium induced stimulation of enzymes are of a magnitude comparable with maximal stimulation by hormonal and cholinergic secretagogues, ${ }^{42931}$ finally, the response to subsequent secretagogue stimulation is not altered by preceding exposure to high calcium concentrations. ${ }^{+4}$ In conclusion, the available data are consistent with intrinsic stimulation of pancreatic secretion by hypercalcaemia.

Supported by Deutsche Forschungsgemeinschaft, grants HO 500/4-6 and LA 483/2-1.

\section{References}

1 Goebell H, Steffen C, Baltzer G, Bode C. Stimulation of pancreatic secretion of enzymes by acute hypercalcemia in man. Eur J Clin Invest 1973; 3: 98-104.

2 Hotz J, Minne H, Ziegler R. The influence of acute hyper- and hypocalcemia and of calcitonin on exocrine pancreatic function in man. Res Exp Med (Berl) 1973; 160: $152-65$.

3 Malagelada JR, Holtermüller KG, Sizemore GW, Go VLW. The influence of hypercalcemia on basal pancreatic, gallbladder and gastric functions in man. Gastroenterology 1976; 71: 405-8.

4 Layer P, Hotz J, Schmitz-Moormann HP, Goebell H. Effects of experimental chronic hypercalcemia on feline exocrine pancreatic secretion. Gastroenterology 1982; 82: 309-16.

5 Cope O, Culver PJ, Mixter CG, Nardi GL. Pancreatitis, a diagnostic clue to hyperparathyroidism. Ann Surg 1957; 145: 857-63.

6 Mixter CG, Keynes WM, Cope O. Further experience with pancreatitis as a diagnostic clue to hyperparathyroidism. N Engl J Med 1962; 266: 265-72.

7 Kelly RT, Falor WH. Hyperparathyroid crises associated with pancreatitis. Ann Surg 1968; 168: 917-26.

8 Kistler H. Primärer Hyperparathyreoidismus. Eine Analyse von 152 Patienten unter besonderer Berücksichtigung akuter lebensbedrohlicher Komplikationen (Akuter Hyperparathyreoidismus). Schweiz Med Wochenschr 1976; 3: suppl: 1-61.

9 Layer P, Hotz J, Eysselein VE, et al. Effects of acute hypercalcemia on exocrine pancreatic secretion in the cat. Gastroenterology 1985; 88: 1168-74. 
10 Eagle H. Amino acid metabolism in mammalian cell cultures. Science 1959; 130: 432-7.

11 Scheele GA, Palade GE. Studies on the guinea pig pancreas: parallel discharge of exocrine enzyme activities. J Biol Chem 1975; 250: 266()-70.

12 Bieger W, Kern HF. Studies on intracellular transport in the rat exocrine pancreas. I. Inhibition by aromatic amino acids in vitro. Virchows Arch [Pathol Anat] 1975; 367: 289-305.

13 Layer P, Hotz J, Maruhn D, Goebell H. Determination of calcium concentrations in pancreatic juice with the Corning 940 calcium titrator. Clin Chem 1983; 29: 745 .

14 Moore EW. Ionized in normal serum, ultrafiltrate and whole blood determined by ion exchange electrodes. J Clin Invest 1970; 49: 318-34.

15 Drop LJ, Tochka LN, Misiano DR. Comparative evaluation of two calcium ion-selective electrode systems, and their utility for monitoring steady state changes in $\mathrm{Ca}^{2+}$. Clin Chem 1982; 28: 129-33.

16 Jamieson JD, Palade GE. Condensing vacuoles conversion and zymogen granule discharge in pancreatic exocrine cells: metabolism studies. J Cell Biol 1971; 48: $503-22$.

17 Hummel BC. A modified spectrophotometric determination of chymotrypsin, trypsin, and thrombin. Can $J$ Biochem 1955; 37: 1393-7.

18 Bernfeld P. Amylase $\alpha$ and $\beta$. In: Colowick CO, Kaplan NO, eds. Methods of enzymology. New York: Academic Press Inc, 1955; 1: 149-58.

19 Box GEP, Hunter WG, Hunter JS. Statistics for experimenters. New York: John Wiley, 1978: 306-42.

20 Frick TW, Runge W, Sibley RK, Satterberg TL, Gooddale RL. Calcium infusion and pancreatic ultrastructure in the cat [Abstract]. Dig Dis Sci 1985; 30: 971.

21 Tiscornia O, Palasciano G, Dzieniszewski J, Verine $\mathbf{H}$,
Sarles H. Analysis of the mechanism of action on calcium induced exocrine pancreatic secretory changes in the dog. Am J Gastroenterology 1975; 63: 293-8.

22 Ziegler R, Minne H. Flicker M. Hotz J. Unresponsiveness of exocrine rat pancreas to calcemic challenges (hypercalcemia, EDTA-hypocalcemia, or calcitonin administration) which influence stomach function. Res Exp Med (Berl) 1976; 169: 347-50.

23 Katz B, Miledi R. The effect of calcium on acetylcholine release from motor nerve terminals. Proc $R$ Soc $B$ 1975; 161: $496-503$.

24 Schulz I. The role of extracellular $\mathrm{Ca}^{2+}$ and cyclic nucleotides in the mechanism of enzyme secretion from the cat pancreas. Pflugers Arch 1975; 360: 165-81.

25 Petersen $\mathrm{OH}$, Ueda N. Pancreatic acinar cells: the role of calcium in stimulus-secretion coupling. J Physiol 1976; 254: 585-606.

26 Argent BE, Case RM, Scratcherd T. Amylase secretion by the perfused cat pancreas in relation to the secretion of calcium and as influences by the external ionic environment. $J$ Physiol 1973; 230: 575-93.

27 Teufel H, Stock P, Rohrmoser H, Forell MM. Der Einfluss des extrazellulären Calciums auf die Saft-, Enzym- und Calciumsekretion des isoliert perfundierten Hundepankreas. Res Exp Med 1977; 169: 221-41.

28 Argent BE, Case RM, Scratcherd T. Stimulation of amylase secretion from the perfused cat pancreas by potassium and other alkali metal ions. J Physiol 1971; 216: 611-24.

29 Layer P, Hotz J, Goebell H. Calcium secretion from the feline pancreas: influence of hormonal and cholinergic secretagogues and of serum calcium. Digestion 1983; 26: 89-98.

30 Layer P, Hotz J, Goebell H. The stimulatory effect of hypercalcemia on pancreatic secretion is prevented by pretreatment with cholecystokinin and cholinergic agonists. Pancreas 1986; 1: 478-82. 